\title{
Rapid Flow Cytometry of Gastrointestinal Stromal Tumours Closely Matches the Modified Fletcher Classification
}

\author{
KIYOAKI TANIGUCHI ${ }^{1}$, AKANE SUZUKI ${ }^{2}$, AKIKO SERIZAWA $^{1}$, SHO KOTAKE ${ }^{1}$, \\ SHUNICHI ITO ${ }^{1}$, KAZUOMI SUZUKI ${ }^{1}$, TAKUJI YAMADA ${ }^{1}$, TAKEHARU NOGUCHI ${ }^{1}$, \\ KUNIHIKO AMANO $^{1}$, MASAHO OTA ${ }^{1}$, YOSHIHIRO MURAGAKI ${ }^{3}$ and MASAKAZU YAMAMOTO ${ }^{1}$ \\ ${ }^{1}$ Department of Surgery, Institute of Gastroenterology, Tokyo Women's Medical University, Tokyo, Japan; \\ ${ }^{2}$ Nihon Kohden Corporation, Tokyo, Japan; \\ ${ }^{3}$ Department of Neurosurgery, Faculty of Advanced Techno-Surgery, \\ Graduate School of Medicine, Tokyo Women's Medical University, Tokyo, Japan
}

\begin{abstract}
Aim: We aimed to develop a rapid, simple procedure and an algorithm for quantitative analysis and classification of the metastatic risk of gastrointestinal stromal tumours (GIST) for clinical use. Materials and Methods: Eighteen specimens from laparoscopic local gastrectomy were assessed by flow cytometry. We devised a new risk classification for GIST by combining flow cytometry parameters with tumour size and evaluated whether the combined parameters correlated with the modified Fletcher risk classification. Results: We found a significant correlation between clinical prognostic factors (mitotic count and Ki-67 labelling index) and the flow cytometry parameters DNA ploidy, DNA index and S-phase fraction. The combined parameters established from tumour size and the flow cytometry parameters showed a high correlation with the modified Fletcher risk classification ( $p=0.0064)$. Flow cytometry had to be performed for approximately 10 minutes to determine the metastatic risk. Conclusion: Rapid flow cytometry parameters can classify risk without the need for histological analysis.
\end{abstract}

Currently, the metastatic risk of gastrointestinal stromal tumours (GIST) is predicted by tumour size, mitotic count, tumour location, and presence or absence of tumour rupture (1-3). The number of mitotic figures per 50 high-power fields (HPF) and a positive rate of the Ki-67 labelling index (Ki-67 LI) $>6 \%$, assessed with a $40 \times$ objective lens, are commonly

This article is freely accessible online.

Correspondence to: Kiyoaki Taniguchi, Department of Surgery, Institute of Gastroenterology, Tokyo Women's Medical University, 8-1 Kawada-cho, Shinjuku-ku, Tokyo, 162-8666, Japan. Tel: +81 3335381111, Fax: +81 352697507, e-mail: ktaniguchi@twmu.ac.jp

Key Words: Gastrointestinal stromal tumour, flow cytometry, risk classification, DNA ploidy. used to estimate cell proliferation potential. However, the pathological diagnostic process requires many time-consuming procedures. Cell cycle analysis with digital flow cytometry is another method to assess cell division and proliferation in tissue specimens (4-8). The correlation of flow cytometry histograms obtained from cell proliferation potency with the specific flow cytometry patterns of GIST have previously been reported (9-11). However, flow cytometry has not been adopted in clinical studies because of the skilled preparation and technical requirements involved.

Here, we propose a rapid, simple procedure and an algorithm for quantitative analysis for clinical use that correlates with clinical prognostic factors: DNA ploidy analysis by rapid flow cytometry reflects the mitotic rate, which allows risk to be classified on the basis of flow cytometry parameters without the need for histological analysis.

\section{Materials and Methods}

Patient characteristics and flow cytometry assay. This study was conducted with the approval of the institutional review board at Tokyo Women's Medical University (approval no. 3257). All procedures were performed at Tokyo Women's Medical University between 2014 and 2018. Patient characteristics are shown in Table I.

Eighteen specimens taken after laparoscopic local gastrectomy for GIST were measured by flow cytometry with the methodology used in previous studies $(12,13)$. Briefly, a $\sim 3 \mathrm{~mm}$-sized piece of tissue was cut from a fresh surgical specimen. All specimens were collected from the centre of the tumour, placed in a microtube and immersed in a staining reagent kit (FC-220V; Nihon Kohden Corporation, Tokyo, Japan) $(12,13)$ that included ribonuclease A, TritonX-100 and propidium iodide. The specimen was then disrupted by repetitive pipetting for $200 \mathrm{~s}$ with an automatic cell isolation system for flow cytometry consisting of a cell isolation unit and a staining reagent kit prototype device (Nihon Kohden Corporation, Tokyo, Japan) (14). DNA aneuploidy (DA), DNA index (DI) and S-phase fraction (SPF) were obtained from the flow cytometry histogram. The actual time required for flow cytometry was $\sim 10 \mathrm{~min}$. 
Flow cytometry parameters (DA, DI and SPF). Ploidy analysis with flow cytometry can reveal the DNA heterogeneity of cells. The peaks detected in the histograms represent the number of chromosomes in the analyzed cells. DA was seen on the histogram as a different peak from the diploidy peak. The DI was applied to determine whether a detected peak was DA. A DI value of 1.0 was determined as the position relative to the diploid peak of normal cells on the histogram. Next, to evaluate the presence of a significant correlation with the clinical prognostic factors we defined a DI cut-off value of 1.3 as indicating DA. If cells could not be distinguished from the $\mathrm{G}_{2} / \mathrm{M}$ phase of diploid cells, DNA was not considered to be aneuploid (i.e., if $1.90<\mathrm{DI}<2.10)(15)$. The SPF was defined as the mean of the cell counts in the area of the flat part of the histogram between the $G_{0} / G_{1}$ and $G_{2} / M$ peaks (16).

Clinical prognostic factor grading. Clinical factors were investigated as potential prognostic factors that obeyed the Fletcher and Miettinen classifications, including tumour diameter $(\geq 5 \mathrm{~cm} v s$. $\geq 2 \mathrm{~cm}$ and $<5 \mathrm{~cm} v s .<2 \mathrm{~cm})$, mitotic count $(\geq 5 / 50 \mathrm{HPF} v s .<5 / 50$ $\mathrm{HPF})$ and $\mathrm{Ki}-67 \mathrm{LI}(\geq 6 \%$ vs. $<6 \%)(17-20)$.

Statistical analysis. First, we compared the accuracy of the flow cytometry factors with that of the clinical prognostic factors (mitotic count and Ki-67 LI) by Pearson's chi-squared test. Next, we used the flow cytometry parameters that showed significant accuracy in the first analysis (i.e., DA, DI and SPF) and tumour size to develop a new risk classification. Subsequently, we compared the accuracy of this new risk classification with that of the modified Fletcher risk classification with Pearson's chi-squared test. Histograms were analysed with MATLAB (version R2015b, Mathworks, Natick, MA, USA) and statistical analyses were performed with JMP software (version 14, SAS Institute, Cary, NC, USA).

\section{Results}

Correlation of flow cytometry parameters and clinical prognostic factors. Table II shows the association of clinical prognostic factors (tumour size, Ki-67 LI and mitotic count) and flow cytometry parameters (DA, DI and SPF) with the modified Fletcher classification in the individual participants. All correlations were low or intermediate.

The accuracy of flow cytometry parameters for identifying clinical prognostic factors. The cut-off values for the mitotic count and Ki-67 LI were chosen on the basis of the Fletcher and Miettinen classifications. The accuracy of the flow cytometry parameters DA, DI and SPF for identifying a mitotic count $\leq 5$ were $88.9 \% \quad(95 \% \quad \mathrm{CI}=69.6-96.9$; $p=0.0022), 83.3 \% \quad(95 \% \quad \mathrm{CI}=65.4-92.2, p=0.0168)$ and $94.4 \%$ (95\% CI=76.8-94.4, $p=0.0003$ ), respectively. The accuracy of the flow cytometry parameters DA, DI and SPF for identifying a Ki-67 LI $\leq 6$ were $83.3 \%$ (95\% CI=63.392.2, $p=0.0092), 77.8 \%$ (95\% CI=59.6-86.7, $p=0.0045)$ and $88.9 \%$ (95\% CI=70.5-88.9, $p=0.0013)$, respectively. However, the tumour size did not significantly correlate with any of the flow cytometry parameters (Table III).
Table I. Patient characteristics.

\begin{tabular}{lc}
\hline Gender $(\mathrm{M} / \mathrm{F})$ & $8 / 10$ \\
Age $(\mathrm{Mean} \pm \mathrm{SD})$ & $63.6 \pm 12.0$ \\
Tumor size $(\mathrm{cm})$ & $4.27 \pm 1.84$ \\
Mitosis count $(\mathrm{HPF})$ & $1.2 \pm 1.2$ \\
Ki-67 LI $(\%)$ & $3.9 \pm 3.2$ \\
Risk classification with modified-Fletcher & \\
Low risk & 10 \\
Intermediate risk & 6 \\
High risk & 2 \\
\hline
\end{tabular}

New risk classification for GIST on the basis of flow cytometry parameters. In our new risk classification of GIST, we replaced mitotic count with the flow cytometry parameters in the modified Fletcher classification. We defined the 3 risk levels as follows (see Table IV): low risk=tumour size $\leq 5 \mathrm{~cm}$, absence of DA and DI $<1.5$ and $\mathrm{SPF}<2$; intermediate risk $=$ tumour size $\leq 5 \mathrm{~cm}$, presence of DA or DI $\geq 1.5$ or $\mathrm{SPF} \geq 2$ or tumour size between 5.1 and 10 $\mathrm{cm}$, absence of DA and DI $<1.5$ and SPF $<2$; high risk=tumour size between 5.1 and $10 \mathrm{~cm}$ and presence of DA or $\mathrm{DI} \geq 1.5$ or $\mathrm{SPF} \geq 2$ or tumour size $>10 \mathrm{~cm}$.

Correlation of tumour size with flow cytometry parameters and risk classification. We found a significant correlation between the modified Fletcher classification and the combined parameters established from tumour size and flow cytometry parameters $(p=0.0064)$.

When we compared our risk classification of low-risk GIST with the modified Fletcher classification, we found a value of $94.4 \%$ for accuracy, $100 \%$ for sensitivity, $87.5 \%$ for specificity, $90.9 \%$ for positive predictive value and $100 \%$ for negative predictive value. In the comparison of intermediaterisk GIST, the values were as follows: accuracy of $88.9 \%$, sensitivity of $71.4 \%$, specificity of $100 \%$, positive predictive value of $100 \%$ and negative predictive value of $84.6 \%$. The values for high-risk GIST were as follows: accuracy of $94.4 \%$, sensitivity of $100 \%$, specificity of $94.1 \%$, positive predictive value of $50 \%$ and negative predictive value of 100\% (Table V).

\section{Discussion}

In this study, we were able to devise a new risk classification of GIST by combining flow cytometry parameters with tumour size and to demonstrate that the combined parameters correlate with the modified Fletcher risk classification. Previous reports showed that specific flow cytometry patterns correlate with the cell proliferation potency of GIST (21-23), suggesting that they could be used as an accurate method for classifying risk without a need for histological diagnosis. 
Table II. Clinical and flow cytometry parameters.

\begin{tabular}{|c|c|c|c|c|c|c|c|c|}
\hline \multirow[b]{2}{*}{ Age } & \multirow[b]{2}{*}{ Gender } & \multicolumn{3}{|c|}{ Clinical parameters } & \multicolumn{3}{|c|}{ Flow cytometry parameters } & \multirow[b]{2}{*}{$\begin{array}{l}\text { Modified-Fletcher } \\
\text { classification }\end{array}$} \\
\hline & & $\begin{array}{l}\text { Tumor size } \\
\quad(\mathrm{cm})\end{array}$ & $\begin{array}{l}\text { Mitotic count } \\
\quad \text { (number) }\end{array}$ & $\begin{array}{c}\text { Ki-67 LI } \\
(\%)\end{array}$ & DA & DI & SPF & \\
\hline 57 & $\mathrm{~F}$ & 34 & 0 & 3 & 0 & 2.00 & 0.31 & Low \\
\hline 72 & $\mathrm{~F}$ & 38 & 0 & 3 & 0 & $1.12 / 1.26$ & 0.32 & Low \\
\hline 67 & $\mathrm{~F}$ & 60 & 0 & 2 & 0 & 1.17 & 0.73 & Intermediate \\
\hline 65 & M & 30 & 0 & 0 & 1 & $2.01 / 3.15$ & 0.31 & Low \\
\hline 75 & $\mathrm{~F}$ & 30 & 1 & 0 & 0 & 1.99 & 1.58 & Low \\
\hline 67 & M & 35 & 0 & 7 & 1 & $1.55 / 2.76$ & 17.9 & Intermediate \\
\hline 52 & M & 30 & 2 & 1 & 0 & NA & 1.95 & Low \\
\hline 45 & $\mathrm{~F}$ & 47 & 3 & 3 & 0 & $1.18 / 1.97$ & 0.22 & Intermediate \\
\hline 60 & M & 72 & 7 & 5 & 0 & 1.99 & 0.84 & High \\
\hline 52 & $\mathrm{~F}$ & 32 & 2 & 5 & 0 & NA & 0.25 & Low \\
\hline 69 & $\mathrm{~F}$ & 42 & 7 & 15 & 1 & 1.53 & 4.25 & Intermediate \\
\hline 79 & $\mathrm{~F}$ & 28 & 4 & 10 & 0 & $1.23 / 2.03$ & 0.19 & Low \\
\hline 49 & $\mathrm{~F}$ & 28 & 1 & 7 & 0 & 1.18 & 0.28 & Low \\
\hline 69 & M & 43 & 8 & 10 & 1 & 1.42 & 2.89 & Intermediate \\
\hline 85 & $\mathrm{~F}$ & 80 & 1 & 5 & 0 & $1.22 / 1.95$ & 0.56 & Intermediate \\
\hline 63 & M & 80 & 14 & 15 & 1 & $1.54 / 1.94$ & 4.94 & High \\
\hline 44 & M & 44 & 0 & 5 & 0 & 1.24 & 0.79 & Low \\
\hline 75 & $\mathrm{M}$ & 17 & 1 & 5 & 0 & 1.98 & 0.65 & Low \\
\hline
\end{tabular}

Table III. Accuracy of flow cytometry parameters for identifying clinical prognostic factors.

\begin{tabular}{|c|c|c|c|c|}
\hline Clinical prognostic factors & & Flow cytometry parameters & Accuracy \% (95\% CI) & $p$-Value \\
\hline \multirow{3}{*}{ Tumor size } & \multirow{3}{*}{ vs. } & DNA aneuploidy & $38.9 \%(21.6-47.9)$ & 0.8882 \\
\hline & & DNA index & $66.7 \%(57.7-82.9)$ & 0.8796 \\
\hline & & $S$ phase fraction & $5.6 \%(5.6-23.2)$ & 0.6230 \\
\hline \multirow{3}{*}{ Mitotic count } & \multirow{3}{*}{$v s$} & DNA aneuploidy & $88.9 \%(69.6-96.9)$ & $0.0022 *$ \\
\hline & & DNA index & $83.3 \%(65.4-92.2)$ & $0.0168 *$ \\
\hline & & $S$ phase fraction & $94.4 \%(76.8-94.4)$ & $0.0003 *$ \\
\hline \multirow{3}{*}{ Ki-67 LI } & \multirow{3}{*}{ vs. } & DNA aneuploidy & $83.3 \%(63.3-92.2)$ & $0.0092 *$ \\
\hline & & DNA index & $77.8 \%(59.6-86.7)$ & $0.0045^{*}$ \\
\hline & & $S$ phase fraction & $88.9 \%(70.5-88.9)$ & $0.0013 *$ \\
\hline
\end{tabular}

$* p<0.05$.

Currently, GIST risk is stratified on the basis of tumour size, mitotic count, tumour location and the presence or absence of tumour rupture. The mitotic count is commonly used as an index of the cell proliferation potential, which is estimated from the number of mitotic figures per $50 \mathrm{HPF}$ and a Ki-67positive rate $>6 \%$ with a $40 \times$ objective lens (24-26).

Fletcher et al. suggested that the mitotic count should be standardised according to the surface area examined (based on the size of the HPF). However, no agreed-upon definitions exist (1), even though such mitotic counts may still prove useful $(1,27,28)$. We chose to focus on current flow cytometry parameters because cell cycle analysis with flow cytometry is a common method for analysing ploidy and proliferation in clinical specimens. We confirmed a significant correlation between clinical prognostic factors (MC, Ki-67 LI and SPF) and flow cytometry values and therefore propose a rapid, simple procedure and an algorithm for quantitative analysis for clinical use.

Flow cytometry is a technology that can identify the abnormal division of malignant cells, in which cellular DNA 
Table IV. New risk classification by flow cytometry parameters.

\begin{tabular}{|c|c|c|c|c|c|c|}
\hline & \multirow[b]{2}{*}{ Tumor size $(\mathrm{cm})$} & \multicolumn{5}{|c|}{ Flow cytometry parameters } \\
\hline & & DNA aneuploidy & & DNA index & & $\mathrm{S}$ phase fraction \\
\hline Low risk & $\leq 5.0$ & Absence & and & $<1.5$ & and & $<2$ \\
\hline Intermediate risk & $\begin{array}{c}\leq 5.0 \\
5.1 \sim 10.0\end{array}$ & $\begin{array}{l}\text { Presence } \\
\text { Absence }\end{array}$ & $\begin{array}{l}\text { or } \\
\text { and }\end{array}$ & $\begin{array}{l}\geq 1.5 \\
<1.5\end{array}$ & $\begin{array}{l}\text { or } \\
\text { and }\end{array}$ & $\begin{array}{l}\geq 2 \\
<2\end{array}$ \\
\hline High risk & $\begin{array}{c}5.1 \sim 10.0 \\
>10.0\end{array}$ & Presence & or & $\begin{array}{c}\quad \geq 1.5 \\
\text { Any results }\end{array}$ & or & $\geq 2$ \\
\hline
\end{tabular}

Table V. Accuracy of new risk classification.

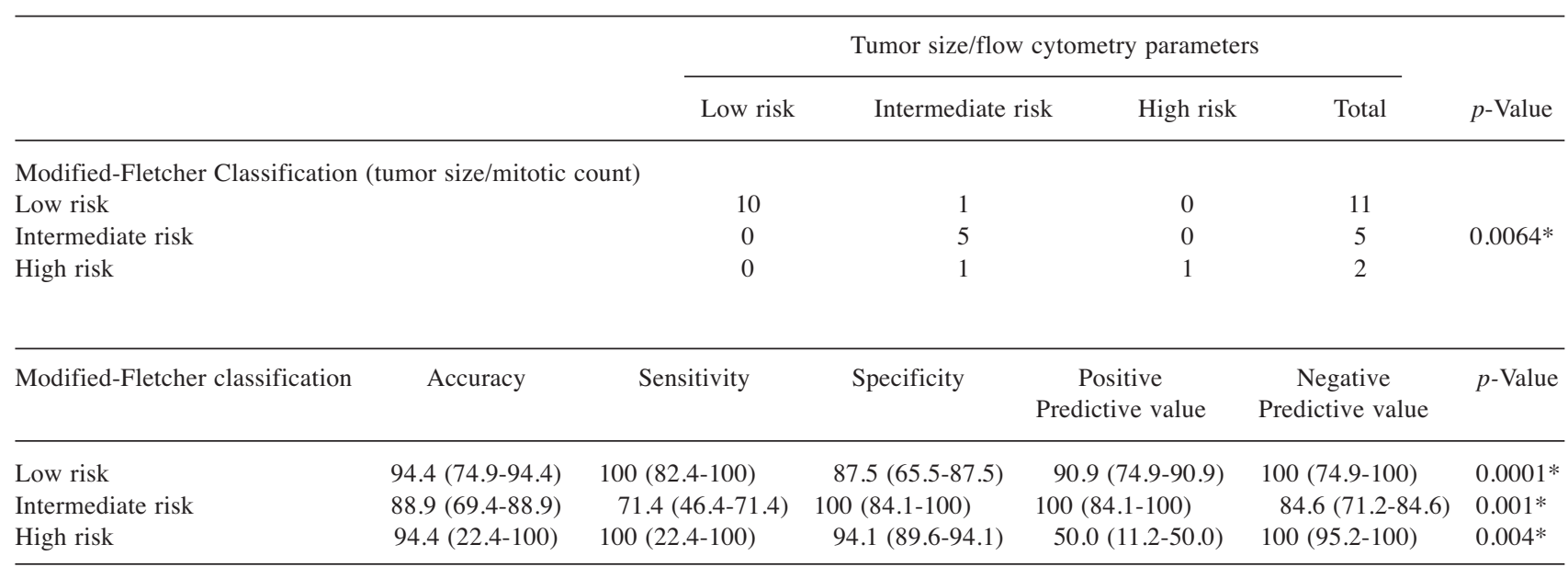

$* p<0.05$.

is stained with fluorescent dyes (9-11). To date, flow cytometry is not in clinical use because preparation of the chemical reagent is troublesome, pre-treatment of the sample needs time and use of the flow cytometer is operator dependent, i.e., the results are not reproducible. We previously reported on a grading system for malignant brain tumours, in which Shioyama et al. used flow cytometry during an operation (12). In this report, pre-treatment was simplified by using a commercial preparation (FC-220V) for the chemical reagent mixture. The pipetting method, which used an automatic cell isolation system and staining reagent kit to separate the cell nuclei from the cells, further shortened the required time. This technology allowed a measurement to be obtained within 10 minutes. The information obtained by intraoperative flow cytometry correlated closely with the pathological diagnosis and enabled the diagnosis of GIST (29).

Cells with heteromerous DNA content show DA, which is equivalent to the peak that is distinct from the diploid peak on a DNA histogram. DI is applied to determine whether a detected peak corresponds to a polyploidy profile. Furthermore, the correlation between SPF and Ki-67 LI is reported. The SPF corresponds to DNA replication, which occurs between the $G_{1}$ and $G_{2}$ phases, and the SPF ratio is correlated to tumour aggressiveness. In this study, we compared SPF distribution in the group with a $\mathrm{Ki}-67 \mathrm{LI}$ value $\geq 6 \%$ and the group with a Ki$67 \mathrm{LI}$ value $<6 \%$. The SPF ratio was significantly higher in the former group (29). It is noteworthy that we identified a significant correlation between the modified Fletcher classification, tumour size and the combined parameters.

Most gastrointestinal tumours are diagnosed by endoscopic biopsy. However, submucosal tumours, such as GIST and leiomyoma, are difficult to diagnose because the results of biopsies are frequently negative. Endoscopic ultrasonography-guided fine-needle aspiration (EUS-FNA) has been widely performed to aid in diagnosing these tumours and was suggested for the differential diagnosis of gastric submucosal tumours, especially to differentiate GIST from other submucosal tumours (30-33). 
Flow cytometry lasting approximately 10 minutes was required to classify risk from an unfixed specimen. Rapid flow cytometry parameters have been suggested for evaluating samples obtained by biopsy and EUS-FNA and this study showed that these parameters are useful for the risk classification of GIST without having to perform a histological diagnosis.

\section{Conflicts of Interest}

This study was conducted under a collaborative research agreement between Tokyo Women's Medical University and the Nihon Kohden Corporation for the voluntary lease of the pipetting device used for tissue preparation.

\section{Authors' Contributions}

T.K. made substantial contributions to the conception, design and data acquisition, analysis and interpretation and participated in drafting the article. S.A. made substantial contributions to the analysis and interpretation of the data and participated in critically reviewing and revising the article for intellectual content. Y.T., S.A., N.T., A.K., K.S., I.S. and S.K. made substantial contributions to data acquisition and participated in drafting the article. O.A. made substantial contributions to data acquisition and participated in critically reviewing and revising the article for intellectual content. M.Y. and Y.M. made substantial contributions to the analysis and interpretation of data and participated in critically reviewing and revising the article for intellectual content. All Authors approved the final version for publication.

\section{Acknowledgements}

The Authors are grateful to all staff members of the Department of Neurosurgery and the Faculty of Advanced Techno-Surgery, Tokyo Women's Medical University as well as to all staff members of the Ogino Memorial Laboratory at Nihon Kohden Corporation for help provided during this study. The Authors also wish to thank Libby Cone, MD, MA, and Jacquie Klesing, Board-certified Editor in the Life Sciences (ELS), of Yamada Translation Bureau, Inc., Tokyo, Japan (https://www.ytrans.com/home.html), for writing and editing assistance.

\section{References}

1 Fletcher CD, Berman JJ, Corless C, Gorstein F, Lasota J, Longley BJ, Miettinen M, O'Leary TJ, Remotti H, Rubin BP, Shmookler B, Sobin LH and Weiss SW: Diagnosis of gastrointestinal stromal tumors: A consensus approach. Hum Pathol 33(5): 459-465, 2002. PMID: 12094370. DOI: 10.1053/hupa.2002.123545

2 Wong NA, Young R, Malcomson RD, Nayar AG, Jamieson LA, Save VE, Carey FA, Brewster DH, Han C and Al-Nafussi A: Prognostic indicators for gastrointestinal stromal tumours: a clinicopathological and immunohistochemical study of 108 resected cases of the stomach. Histopathology 43(2): 118-126, 2003. PMID: 12877726. DOI: 10.1046/j.1365-2559.2003.01665.x

3 Singer S, Rubin BP, Lux ML, Chen CJ, Demetri GD, Fletcher $\mathrm{CD}$ and Fletcher JA: Prognostic value of KIT mutation type, mitotic activity, and histologic subtype in gastrointestinal stromal tumors. J Clin Oncol 20(18): 3898-3905, 2002. PMID: 12228211. DOI: $10.1200 / \mathrm{JCO} .2002 .03 .095$

4 Dahm HH, von der Haar $\mathrm{C}$ and Rübben $\mathrm{H}$ : DNA cytophotometric and histological analysis of N-butyl-N-(4hydroxybutyl)nitrosamine-induced precancerous lesions of the bladder urothelium. J Cancer Res Clin Oncol 142(6): 1253-1260, 2016. PMID: 27033373. DOI: 10.1007/s00432-016-2153-0

5 Koss LG, Czerniak B, Herz F and Wersto RP: Flow cytometric measurements of DNA and other cell components in human tumors: a critical appraisal. Hum Pathol 20(6): 528-548, 1989. PMID: 2470666. DOI: 10.1016/0046-8177(89)90244-x

6 Ballantyne KC, James PD, Robins RA, Robins RA, Baldwin RW and Hardcastle JD: Flow cytometric analysis of the DNA content of gastric cancer. Br J Cancer 56: 52-54, 1987. PMID: 3620318. DOI: $10.1038 /$ bjc.1987.152

7 Rabson AR: Flow cytometry in the diagnosis of brain tumors. Neurosurg Clin N Am 5: 135-146, 1994. PMID: 8124088.

8 Araya JC, Roa I, Wistuba I, Villaseca MA, Contreras E, Olcese A, Danton A and Watanabe H: Breast cancer and flow cytometry: comparative study of DNA ploidy pattern with clinicopathological parameters. Rev Med Chil 122: 643-652, 1994. PMID: 7732208.

9 Quirke P, Fozard JB, Dixon MF, Dyson JE, Giles GR and Bird CC: DNA aneuploidy in colorectal adenomas. Br J Cancer 53: 477-481, 1986. PMID: 3707842. DOI: 10.1038/bjc.1986.75

10 Sánchez-Pérez I, García Alonso P and Belda Iniesta C: Clinical impact of aneuploidy on gastric cancer patients. Clin Trans1 Oncol 11: 493-498, 2009. PMID: 19661021. DOI: 10.1007/ s12094-009-0393-Z

11 Børkje B, Høstmark J, Skagen DW, Schrumpf E and Lærum OD: Flow cytometry of biopsy specimens from ulcerative colitis, colorectal adenomas, and carcinomas. Scand J Gastroenterol 22: 1231-1237, 1987. PMID: 3433012. DOI: 10.3109/003655 28708996469

12 Shioyama T, Muragaki Y, Maruyama T, Komori T and Iseki H: Intraoperative flow cytometry analysis of glioma tissue for rapid determination of tumor presence and its histopathological grade. J Neurosurg 118: 1232-1238, 2013. PMID: 23432426. DOI: 10.3171/2013.1.JNS12681

13 Oya S, Yoshida S, Tsuchiya T, Fujisawa N, Mukasa A, Nakatomi $\mathrm{H}$, Saito $\mathrm{N}$ and Matsui $\mathrm{T}$ : Intraoperative quantification of meningioma cell proliferation potential using rapid flow cytometry reveals intratumoral heterogeneity. Cancer Med 8: 2793-2801, 2019. PMID: 30993844. DOI: 10.1002/cam4.2178

14 Mimura-Kimura Y, Shioyama T, Suzuki A, Amano Y, Kubo H, Mimura Y, Kobayashi N and Murakami T: Influence of cell preparation method on flow cytometric analysis of DNA aneuploidy - Comparison of the new cell-preparation system FC-210V/ACI-X with the conventional method recommended by Japan Committee for Certified Cytometrist. Cytometry Res 27: 1-7, 2017. DOI: 10.18947/cytometryresearch.27.2_1

15 Suzuki A, Maruyama T, Nitta M, Komori T, Ikuta S, Chernov M, Tamura M, Kawamata T and Muragaki Y: Evaluation of DNA ploidy with intraoperative flow cytometry may predict long-term survival of patients with supratentorial low-grade gliomas: Analysis of 102 cases. Clin Neurol Neurosurg 168: 46-53, 2018. PMID: 29522936. DOI: 10.1016/j.clineuro.2018.02.027

16 Koriyama S, Nitta M, Kobayashi T, Muragaki Y, Suzuki A, Maruyama T, Komori T, Masui K, Saito T, Yasuda T, Hosono J, Okamoto S, Shioyama T, Yamatani H and Kawamata T: A 
surgical strategy for lower grade gliomas using intraoperative molecular diagnosis. Brain Tumor Pathol 35(3): 159-167, 2018. PMID: 29980868. DOI: 10.1007/s10014-018-0324-1

17 Klieser E, Pichelstorfer M, Weyland D, Kemmerling R, Swierczynski S, Dinnewitzer A, Jäger T, Kiesslich T, Neureiter $\mathrm{D}$ and Illig R: Back to the start: Evaluation of prognostic markers in gastrointestinal stromal tumors. Mol Clin Oncol 4: 763-773, 2016. PMID: 27123276. DOI: $10.3892 / \mathrm{mco} .2016 .819$

18 Liu X, Qiu H, Wu Z, Zhang P, Feng X, Chen T, Li Y, Tao K, Li G, Sun X, Zhou Z, and China Gastrointestinal Stromal Tumor Study Group (CN-GIST): A novel pathological prognostic score (PPS) to identify "very high-risk" patients: a multicenter retrospective analysis of 506 patients with high risk gastrointestinal stromal tumors (GIST). J Gastrointest Surg 22: 2150-2157, 2018. PMID: 30030719. DOI: 10.1007/s11605-018-3799-5

19 Liu X, Qiu H, Zhang P, Feng X, Chen T, Li Y, Tao K, Li G, Sun X and Zhou Z: Ki-67 labeling index may be a promising indicator to identify "very high-risk" gastrointestinal stromal tumor a multicenter retrospective study of 1022 patients. Hum Pathol 74: 17-24, 2018. PMID: 28962945. DOI: 10.1016/j.humpath.2017.09.003

20 Liang YM, Li XH, Li WM and Lu YY: Prognostic significance of PTEN, Ki-67 and CD44s expression patterns in gastrointestinal stromal tumors. World J Gastroenterol 18: 16641671, 2012. PMID: 22529697. DOI: 10.3748/wjg.v18.i14.1664

21 Nesi G, Bruno L, Saieva C, Caldini A, Girardi LR, Zanna I, Rapi S, Bechi P, Cortesini C and Palli D: DNA ploidy and S-phase fraction as prognostic factors in surgically resected gastric carcinoma: A 7-year prospective study. Anticancer Res 27: 44354442, 2007. PMID: 18214057.

22 Carrillo R, Candia A, Rodriguez-Peralto JL and Caz V: Prognostic significance of DNA ploidy and proliferative index (MIB-1 Index) in gastrointestinal stromal tumors. Human Pathol 28(2): 160-165, 1997. PMID: 9023396. DOI: 10.1016/s00468177(97)90100-3

23 Fontana MG, Rossi E, Bassotti G, Aquilano MC, Cadei M, Grigolato P and Villanacci V: Gastrointestinal stromal tumors: Usefulness of immunohistochemistry, flow cytometry and fluorescence in situ hybridization. J. Gastroenterol. Hepatol 22: 1754-1759, 2007. PMID: 17914946. DOI: 10.1111/j.14401746.2006.04530.x

24 Wong NA, Young R, Malcomson RD, Nayar AG, Jamieson LA, Save VE, Carey FA, Brewster DH, Han C and Al-Nafussi A: Prognostic indicators for gastrointestinal stromal tumours: a clinicopathological and immunohistochemical study of 108 resected cases of the stomach. Histopathology 47: 2247-2253, 2000. PMID: 12877726. DOI: 10.1046/j.1365-2559.2003.01665.x

25 Fujimoto Y, Nakanishi Y, Yoshimura K and Shimoda T: Clinicopathologic study of primary malignant gastrointestinal tumor of the stomach, with special reference to prognostic factors: analysis of results in 140 surgically resected patients. Gastric Cancer 6: 39-48, 2003. PMID: 12673425. DOI: $10.1007 / \mathrm{s} 101200300005$
26 Hasegawa T, Matsuno Y, Shimoda $\mathrm{T}$ and Hirohashi S: Gastrointestinal stromal tumor: consistent CD117 immunostaining for diagnosis, and prognostic classification based on tumor size and MIB-1 grade. Hum Pathol 33: 669-676, 2002. PMID: 12152168. DOI: 10.1053 /hupa.2002.124116

27 Joensuu H, Vehtari A, Riihimaki J, Nishida T, Steigen SE, Brabec P, Plank L, Nilsson B, Cirilli C, Braconi C, Bordoni A, Magnusson MK, Linke Z, Sufliarsky J, Federico M, Jonasson JG, Dei Tos AP and Rutkowski P: Risk of recurrence of gastrointestinal stromal tumour after surgery: an analysis of pooled population-based cohorts. Lancet Oncol 13: 265-274, 2012. PMID: 22153892. DOI: 10.1016/S1470-2045(11)70299-6

28 Miettinen $\mathrm{M}$ and Lasota J: Gastrointestinal stromal tumors: pathology and prognosis at different sites. Semin Diag Pathol 23: 70-83, 2006. PMID: 17193820. DOI: 10.1053/j.semdp.2006.09.001

29 Isola JJ, Helin HJ, Helle MJ and Kallioniemi OP: Evaluation of cell proliferation in breast carcinoma. Comparison of Ki-67 immunohistochemical study, DNA flow cytometric analysis, and mitotic count. Cancer 65: 1180-1184, 1990. PMID: 2406010. DOI: 10.1002/1097-0142(19900301)65:5<1180::aid-cncr2820650 $525>3.0 . c 0 ; 2-7$

30 Suzuki T, Arai M, Matsumura T, Arai E, Hata S, Maruoka D, Tanaka T, Nakamoto S, Imazeki $F$ and Yokosuka O: Factors associated with inadequate tissue yield in EUS-FNA for gastric SMT. ISRN Gastroenterol 2011: 619128, 2011. PMID: 21991522. DOI: $10.5402 / 2011 / 619128$

31 Maheshwari V, Alam K, Varshney M, Jain A, Asif Siddiqui F and Bhargava S: Fine-needle aspiration diagnosis of GIST: a diagnostic dilemma. Diagn Cytopathol 40: 834-838, 2012. PMID: 21563325. DOI: 10.1002/dc.21734.

32 Ito $\mathrm{H}$, Inoue $\mathrm{H}$, Ryozawa $\mathrm{S}$, Ikeda $\mathrm{H}$, Odaka N, Eleftheriadis $\mathrm{N}$, Maselli R, Sando N, Kimura S and Kudo S: Fine-needle aspiration biopsy and endoscopic ultrasound for pre-treatment pathological diagnosis of gastric gastrointestinal stromal tumors. Gastroenterol Res Pract 2012: 139083, 2012. DOI: 10.1155/ 2012/139083

33 Mekky MA, Yamao K, Sawaki A, Mizuno N, Hara K, Nafeh MA, Osman AM, Koshikawa T, Yatabe Y and Bhatia V: Diagnostic utility of EUS-guided FNA in patients with gastric submucosal tumors. Gastrointest Endosc 71: 913-919, 2010. PMID: 20226456. DOI: 10.1016/j.gie.2009.11.044

Received November 24, 2020

Revised December 13, 2020

Accepted December 14, 2020 